\title{
Targeted Therapy in HR+ HER2- Metastatic Breast Cancer: Current Clinical Trials and Their Implications for CDK4/6 Inhibitor Therapy and beyond Treatment Options
}

\author{
Constanze Elfgen ${ }^{1,2, *}$ and Vesna Bjelic-Radisic ${ }^{2,3}$ \\ 1 Breast Surgery, Breast-Center Zurich, 8008 Zurich, Switzerland \\ 2 Faculty of Medicine, University of Witten-Herdecke, 58455 Witten, Germany; \\ vesna.bjelic-radisic@helios-gesundheit.de \\ 3 Institute of Gynecology and Obstetrics, University Hospital Wuppertal, 42109 Wuppertal, Germany \\ * Correspondence: constanze.elfgen@brust-zentrum.ch; Tel.: +41-44-533-81-00
}

Citation: Elfgen, C.; Bjelic-Radisic, V. Targeted Therapy in HR+ HER2-

Metastatic Breast Cancer: Current Clinical Trials and Their Implications for CDK4 / 6 Inhibitor Therapy and beyond Treatment Options. Cancers 2021, 13, 5994. https://doi.org/ 10.3390/cancers13235994

Academic Editor: Giuseppe Curigliano

Received: 9 November 2021

Accepted: 27 November 2021

Published: 29 November 2021

Publisher's Note: MDPI stays neutral with regard to jurisdictional claims in published maps and institutional affiliations.

Copyright: (c) 2021 by the authors. Licensee MDPI, Basel, Switzerland. This article is an open access article distributed under the terms and conditions of the Creative Commons Attribution (CC BY) license (https:// creativecommons.org/licenses/by/ $4.0 /)$.
Simple Summary: In the treatment of hormone-receptor positive, HER2 negative metastatic breast cancer, targeted therapy showed improved overall survival and it has become an established treatment within recent years. Some study results conflict with others. As multiple new research articles on this topic have been recently published, this review aims to crystallize the current relevant results.

\begin{abstract}
A metastatic state of breast cancer (MBC) affects hundreds of thousands of women worldwide. In hormone receptor-positive ( $\mathrm{HR}+) /$ human epidermal growth factor receptor 2-negative (HER2-) MBC, cyclin-dependent kinase (CDK)4/6 inhibitors can improve the progression-free survival (PFS), as well as the overall survival (OS), in selected patients and have been established as firstand second-line therapies. However, as MBC remains uncurable, resistance to CDK4/6 inhibitors occurs and requires alternative treatment approaches. Data on targeted therapy continue to mature, and the number of publications has been constantly rising. This review provides a summary and update on the clinical relevance, patient selection, ongoing trials of CDK4/ 6 inhibitors, and further targeted therapy options. It focuses on clinical aspects and practicability, as well as adverse events and patient-reported outcomes.
\end{abstract}

Keywords: CDK4/6 inhibitor; PI3K inhibitor; quality of life in MBC; metastatic breast cancer; targeted therapy; HR-positive breast cancer

\section{Introduction}

Breast cancer $(\mathrm{BC})$ is the most frequent malignant disease in women worldwide, and more than one in five affected women experience a metastatic stage, which is still incurable [1]. Around 75\% of BC patients are diagnosed with a hormone receptor-positive $(\mathrm{HR}+)$, human epidermal growth factor receptor 2-negative (HER2-) type of BC [2]. For these patients, endocrine therapy is a major approach for systemic treatment. Aromatase inhibitors (AI), selective estrogen receptor degraders (SERDs), and selective estrogen receptor modulators (SERMs) play an essential role in this context [3]. However, in metastatic or advanced breast cancer $(\mathrm{MBC} / \mathrm{ABC})$, resistance to endocrine therapy occurs, which partly explains the poor median overall survival (OS) of less than five years after metastasis has been diagnosed [4]. Cancer cells underly a high rate of genetic mutations and dysregulations of the cell-dividing cycle, and the development of drugs that interfere in these dysregulations without affecting the whole organism has been an ambitious project. This is especially true for patients with HR+ MBC. Cyclin-dependent kinase 4/6 (CDK4/6) inhibitors and phosphoinositide 3-kinase (PI3K) inhibitors act as targeted therapies in $\mathrm{HR}+\mathrm{MBC}$ and have shown promising results in clinical studies $[5,6]$. However, some expectations for these drugs could not be fulfilled. As the number of new peer-reviewed 
publications concerning CDK4/6 inhibitors for the therapy of $\mathrm{MBC}$ has risen in recent years, limitations have arisen in real-life settings. Furthermore, mature OS data from earlier significant trials have recently been published. Our review aims to crystallize the current role of CDK4/ 6 inhibitors in MBC, considering clinical studies, real-world data, toxicity, and quality of life (QOL). Furthermore we discuss alternative therapeutic approaches in the case of CDK4/ 6 inhibitor resistance. The review may help oncologist practitioners to determine which patients will benefit from the therapy and those which will probably not.

\section{The Rationale of Targeting CDK4/6 for Breast Cancer Therapy}

Briefly, CDKs are enzymes that play a central role in cell cycle progression. The activated complex of D-type cyclins and CDK4/6 leads to phosphorylation and therefore inactivation of retinoblastoma-associated protein. This process is regulated by genes that are a prerequisite for S-phase entry and cell division [7]. These mechanisms are known in all types of BC. However, estrogen acts as a stimulator of this cascade as activated ER increases the amplification of D cyclins, mitogenic enzymes that are associated with multiple cancers [8]. As the expression of cyclin D is high in HR+ breast cancer, this G1-to-S checkpoint represents an ideal therapeutic target. D-type cyclins bind to CDK4/6, and a deregulation of the CDK4/ 6 pathway can often be observed in HR+ BC (Figure 1) [7-9]. The rationale of pharmaceutical intervention is to inhibit CDK4/6 in HR+ $\mathrm{BC}$, and therefore to interrupt the activating mechanisms and trigger cell cycle arrest. As a first- or secondline therapy in HR+, HER2- MBC, three small molecules inhibitors of CDK4/ 6 with similar mechanisms of action have been approved by the FDA: palbociclib, ribociclib, and abemaciclib [10].

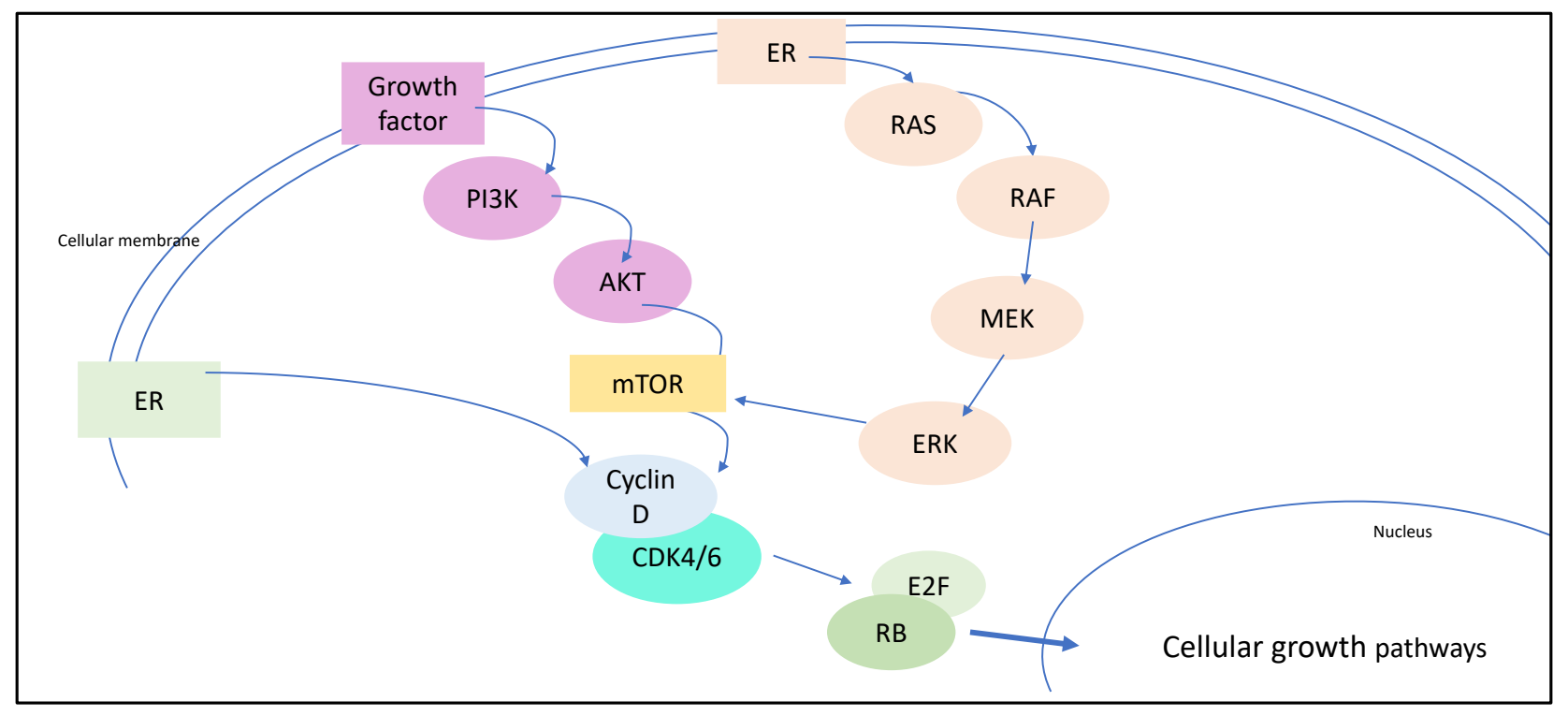

Figure 1. The RAS and PI3K pathway increase mTOR activity which enhance D-type cyclins. The activated complex of Dtype cyclins and CK4/ 6 leads to inactivation of retinoblastoma-associated protein (RB) and therefore to S-phase progression.

The use of CDK4/ 6 inhibitors is standard in combination with the endocrine therapy of an AI, whereas a combination with fulvestrant is preferable in patients who show progressive disease or relapse under AI [11]. Abemaciclib has also been approved as an monotherapeutic agent in heavily pretreated HR+, HER2- MBC patients [12]. CDK4/ 6 inhibitors have significantly improved the progression-free survival (PFS) by several months, compared to endocrine treatment alone, in prospective, randomized clinical trials (Table 1) [13]. Differentiating an OS benefit is challenging in an unselected group of patients with MBC because of the heterogeneity of patients and clinical metastatic manifestations, as well as the variability of previous and subsequent therapies. Furthermore, dose modification and the discontinuation rate may vary much more in patients with $M B C$ than in patients with 
early BC $[14,15]$. All of these aspects complicate the meta-analysis of OS in pivotal clinical trials. Multiple earlier studies and their interim analyses were unable to show a significant improvement in OS when adding a CDK4/6 inhibitor to endocrine therapy (Table 1). As mature OS data containing many years subsequent to the beginning of randomization have been published, we now have a clearer picture of CDK4/6 inhibitors. Recently, the MONALEESA-3 trial revealed a significantly improved OS in MBC patients who received ribociclib plus fulvestrant versus placebo plus fulvestrant (33.6 versus 19.2 months, respectively) [6]. Likewise, the MONALEESA-7 trial emphasized an OS benefit in selected pre-/perimenopausal women who were not heavily pre-treated (as only $14 \%$ received chemotherapy in the advanced setting) [16]. Follow-up data from the MONARCH-2 trial also showed a longer OS in the abemacilib arm (46.7 versus 37.3 months) [17]. However, as the benefit in OS data has been contradictory in previous clinical trials, the question arises as to how patients with an expected benefit can be selected. No significant OS benefit of the third approved CDK4/6 inhibitor (Palbociclib) has been shown to date [18].

Table 1. Relevant prospective, randomized clinical trials on CDK4/6 inhibitors in patients with HR+, HER2- metastatic breast cancer.

\begin{tabular}{|c|c|c|c|c|c|}
\hline Clinical Trial & Patient Selection & $n$ & Therapeutic Regimen & PFS (Months) & OS \\
\hline PALOMA-1 & $\begin{array}{l}\text { Postmenopausal women } \\
\text { without systemic treatment } \\
\text { for advanced disease }\end{array}$ & 165 & $\begin{array}{l}\text { Palbociclib + letrozole versus } \\
\text { letrozole alone }\end{array}$ & $\begin{array}{c}20.2 \text { versus } 10.2 \\
\text { (HR } 0.488,95 \% \mathrm{CI} \\
0.319-0.748 ; \text { one-sided } \\
p=0.0004)\end{array}$ & Not significant \\
\hline PALOMA-2 & $\begin{array}{l}\text { Postmenopausal women } \\
\text { without systemic treatment } \\
\text { for advanced disease }\end{array}$ & 666 & $\begin{array}{l}\text { Palbociclib + letrozole versus } \\
\text { placebo + letrozole }\end{array}$ & $\begin{array}{c}24.8 \text { versus } 14.5 \\
(\mathrm{HR} 0.58 ; 95 \% \mathrm{CI} \\
0.46-0.72 ; p<0.001) \\
\end{array}$ & Immature data \\
\hline PALOMA-3 & $\begin{array}{l}\text { Postmenopausal women } \\
\text { with progress under } \\
\text { endocrine therapy }\end{array}$ & 521 & $\begin{array}{c}\text { Palbociclib + fulvestrant } \\
\text { versus placebo + fulvestrant }\end{array}$ & $\begin{array}{c}9.5 \text { versus } 4.6 \\
(\mathrm{HR} 0.46 ; 95 \% \mathrm{CI} \\
0.36-0.59 ; p<0.0001)\end{array}$ & Not significant \\
\hline MONARCH-2 & $\begin{array}{l}\text { Pre- and postmenopausal } \\
\text { women with progress } \\
\text { under endocrine therapy }\end{array}$ & 669 & $\begin{array}{l}\text { Abemaciclib + fulvestrant } \\
\text { versus placebo + fulvestrant }\end{array}$ & $\begin{array}{c}16.4 \text { versus } 9.3 \\
\text { (HR } 0.553 ; 95 \% \text { CI } 0.449 \\
\text { to } 0.681 ; p<0.001)\end{array}$ & Not significant \\
\hline MONARCH-3 & $\begin{array}{l}\text { Postmenopausal women } \\
\text { without systemic treatment } \\
\text { for advanced disease }\end{array}$ & 493 & $\begin{array}{c}\text { Abemaciclib + endocrine } \\
\text { therapy versus placebo }+ \\
\text { endocrine therapy }\end{array}$ & $\begin{array}{c}28.2 \text { versus } 14.8 \\
\quad(\mathrm{HR} 95 \% ; \mathrm{CI} \\
0.418-0.698 ; p<0.0001)\end{array}$ & Immature data \\
\hline MONALEESA-2 & $\begin{array}{l}\text { Postmenopausal women } \\
\text { without systemic treatment } \\
\text { for advanced disease }\end{array}$ & 668 & $\begin{array}{c}\text { Ribociclib + fulvestrant } \\
\text { versus placebo + fulvestrant }\end{array}$ & $\begin{array}{c}25.3 \text { versus } 16.0 \\
(\mathrm{HR} 0.568 ; 95 \% \mathrm{CI} \\
0.457-0.704 ; p<0.0001)\end{array}$ & Immature data \\
\hline MONALEESA-3 & $\begin{array}{l}\text { Postmenopausal women } \\
\text { without systemic treatment } \\
\text { for advanced disease }\end{array}$ & 726 & $\begin{array}{l}\text { Ribociclib + letrozole versus } \\
\text { placebo + letrozole }\end{array}$ & $\begin{array}{c}20.5 \text { versus } 12.8 \\
(\mathrm{HR} 0.59 ; 95 \% \mathrm{CI} \\
0.48-0.73 ; p>0.001)\end{array}$ & $\begin{array}{c}57.8 \% \text { vs } 45.9 \% \text { at } \\
42 \text { months } \\
\text { (HR 0.72; } 95 \% \text { CI } \\
0.57-0.92 ; p=0.00455)\end{array}$ \\
\hline MONALEESA-7 & Peri-/premenopausal & 672 & $\begin{array}{l}\text { Ribociclib + endocrine } \\
\text { therapy versus placebo }+ \\
\text { endocrine therapy }\end{array}$ & $\begin{array}{c}23.8 \text { versus } 13.0 \\
(\mathrm{HR} 0.55 ; 95 \% \mathrm{CI} \\
0.44-0.69 ; p>0.001)\end{array}$ & $\begin{array}{c}70.2 \% \text { vs } 46.0 \% \text { at } \\
42 \text { months } \\
\text { (HR 0.71; } 95 \% \mathrm{CI} \\
0.54-0.95 ; p=0.00973 \text { ) }\end{array}$ \\
\hline
\end{tabular}

PFS = progression-free survival; $\mathrm{HR}=$ hazard ratio; $\mathrm{OS}=$ overall survival; $\mathrm{CI}=$ confidence interval.

The data are unclear for the subtypes of MBC other than HR+, HER2 -. In HER2+ BC, the oncogenetic activation of the membrane thyrosine kinase HER2 promotes pathogenesis and the progression of cancer cells by interacting with the PI3K/AKT/mTOR pathway and other signaling pathways [19]. Targeted anti-HER2 therapies such as trastuzumab remarkably improved the outcome of HER2+ BC patients. However, resistance to these therapies has been observed and can be mediated by the cyclin D1-CDK4 pathway; inhibiting this axis might decrease the resistance [19]. Despite promising results from earlier transgenic mouse models, the clinical relevance of CDK4/6 inhibitors in HER2+ MBC still has to be defined [19]. Recent data from the monarcHER trial showed an improved PFS in $\mathrm{HR}+, \mathrm{HER} 2+\mathrm{MBC}$ patients who received abemaciclib plus fulvestrant plus trastuzumab 
versus standard-of-care chemotherapy plus trastuzumab [20]. Despite these encouraging results, it has to be qualified with the fact that a control group with endocrine therapy plus trastuzumab was lacking. As multiple trials have been planned and are already running, it is thought that clearer answers to the question of clinical relevance will be provided in the near future (Table 2). This is also true for patients with triple-negative breast cancer (TNBC) (Table 2). Given the mechanism of action of CDK4/6 inhibitors, a therapeutic effect in the heterogeneous group of TNBC is not expected. Nevertheless, in vitro and clinical studies suggest a potential benefit of CDK4/ 6 inhibitors as a pre-treatment to chemotherapy for subgroups of TNBC, especially in cell lines showing the expression and activation of cyclin D1, CDK4/6, and Rb-proficiency [21].

Table 2. Selected ongoing phase II and III trials with CDK4/6 inhibitor therapy.

\begin{tabular}{|c|c|c|c|c|c|c|}
\hline Clinical Trial & Patient Selection & $\begin{array}{c}\text { Estimated } \\
\text { Enrollment }(n)\end{array}$ & Therapeutic Regimen & $\begin{array}{l}\text { Study Start } \\
\text { Year }\end{array}$ & $\begin{array}{c}\text { Estimated } \\
\text { Completion Year }\end{array}$ & $\begin{array}{l}\text { Clinical Trial } \\
\text { Information }\end{array}$ \\
\hline PRESERVE 2 & $\begin{array}{c}\text { Pre- and } \\
\text { postmenopausal } \\
\text { women and men } \\
\text { with metastatic } \\
\text { TNBC }\end{array}$ & 250 & $\begin{array}{c}\text { Trilaciclib + gemcitabine } \\
+ \text { carboplatin versus } \\
\text { placebo + gemcitabine }+ \\
\text { carboplatin }\end{array}$ & 2021 & 2024 & NCT04799249 \\
\hline $\begin{array}{c}\text { Ribociclib with } \\
\text { trastuzumab plus } \\
\text { letrozole in } \\
\text { postmenopausal } \\
\text { HR+, HER2+ ABC } \\
\text { Patients }\end{array}$ & $\begin{array}{l}\text { Postmenopausal } \\
\text { women with } \\
\text { advanced HR+, } \\
\text { HER2+ BC }\end{array}$ & 95 & $\begin{array}{l}\text { Letrozole }+ \\
\text { trastuzumab + ribociclib }\end{array}$ & 2019 & 2021 & NCT03913234 \\
\hline PATRICIA II & $\begin{array}{c}\text { Pre- and } \\
\text { postmenopausal } \\
\text { women with } \\
\text { metastatic HR+ or } \\
\text { HR-, HER2+ BC }\end{array}$ & 232 & $\begin{array}{c}\text { Trastuzumab + } \\
\text { Palbociclib + letrozole } \\
\text { (only in HR+ patients) }\end{array}$ & 2015 & 2020 & NCT02448420 \\
\hline TOUCH & $\begin{array}{l}\text { Pre- and } \\
\text { postmenopausal } \\
\text { women with early } \\
\text { HR+, HER2+ BC }\end{array}$ & 144 & $\begin{array}{c}\text { Paclitaxel }+ \\
\text { trastuzumab }+ \\
\text { pertuzumab versus } \\
\text { Palbociclib + letrozole }+ \\
\text { trastuzumab }+ \\
\text { pertuzumab }\end{array}$ & 2019 & 2021 & NCT03644186 \\
\hline DETECT V & $\begin{array}{l}\text { Pre- and } \\
\text { postmenopausal } \\
\text { women with } \\
\text { metastatic HR+, } \\
\text { HER2+ BC }\end{array}$ & 270 & $\begin{array}{c}\text { Ribociclib }+ \\
\text { trastuzumab }+ \\
\text { pertuzumab }+ \\
\text { endocrine therapy } \\
\text { versus } \\
\text { trastuzumab }+ \\
\text { pertuzumab }+ \\
\text { chemotherapy tailored } \\
\text { by ribociclib }\end{array}$ & 2015 & 2021 & NCT02344472 \\
\hline SONIA & $\begin{array}{c}\text { Pre- and } \\
\text { postmenopausal } \\
\text { women with HR+, } \\
\text { HER2- ad- } \\
\text { vanced/metastatic } \\
\text { breast cancer. }\end{array}$ & 1050 & $\begin{array}{l}\text { Aromatase inhibitor + a } \\
\text { CDK4/6 inhibitor } 1 \text { st } \\
\text { line versus } \\
\text { Fulvestrant }+ \text { CDK } 4 / 6 \\
\text { inhibitor } 2 \text { nd line }\end{array}$ & 2017 & 2022 & NCT03425838 \\
\hline AMICA & $\begin{array}{c}\text { Pre- and } \\
\text { postmenopausal } \\
\text { women with HR+, } \\
\text { HER2- ad- } \\
\text { vanced/metastatic } \\
\text { breast cancer and } \\
\text { disease control after } \\
\text { 1st line } \\
\text { chemotherapy }\end{array}$ & 150 & $\begin{array}{l}\text { Ribociclib + endocrine } \\
\text { therapy versus } \\
\text { endocrine therapy alone }\end{array}$ & 2018 & 2022 & NCT03555877 \\
\hline
\end{tabular}


Table 2. Cont.

\begin{tabular}{|c|c|c|c|c|c|c|}
\hline Clinical Trial & Patient Selection & $\begin{array}{c}\text { Estimated } \\
\text { Enrollment }(n)\end{array}$ & Therapeutic Regimen & $\begin{array}{c}\text { Study Start } \\
\text { Year }\end{array}$ & $\begin{array}{c}\text { Estimated } \\
\text { Completion Year }\end{array}$ & $\begin{array}{l}\text { Clinical Trial } \\
\text { Information }\end{array}$ \\
\hline MAINTAIN & $\begin{array}{c}\text { Pre- and } \\
\text { postmenopausal } \\
\text { women and men } \\
\text { with HR+, HER2- } \\
\text { ad- } \\
\text { vanced/metastatic } \\
\text { breast cancer after } \\
\text { progression on } \\
\text { anti-estrogen } \\
\text { therapy plus } \\
\text { CDK4/6 inhibitor }\end{array}$ & 132 & $\begin{array}{c}\text { Ribociclib + fulvestrant } \\
\text { versus placebo }+ \\
\text { fulvestrant }\end{array}$ & 2016 & 2021 & NCT02632045 \\
\hline ABEMACARE & $\begin{array}{c}\text { Pre- and } \\
\text { postmenopausal } \\
\text { women with HR+, } \\
\text { HER2- ad- } \\
\text { vanced/metastatic } \\
\text { breast cancer and } \\
\text { symptomatic } \\
\text { visceral metastases } \\
\text { or high tumor } \\
\text { burden }\end{array}$ & 120 & $\begin{array}{c}\text { Abemaciclib + } \\
\text { endocrine therapy }\end{array}$ & 2020 & 2024 & NCT04681768 \\
\hline PALATINE & $\begin{array}{c}\text { Pre- and } \\
\text { postmenopausal } \\
\text { women with HR+, } \\
\text { HER2- ad- } \\
\text { vanced/metastatic } \\
\text { breast cancer. }\end{array}$ & 200 & $\begin{array}{l}\text { Palbociclib + endocrine } \\
\text { therapy upfront }\end{array}$ & 2019 & 2023 & NCT03870919 \\
\hline KENDO & $\begin{array}{c}\text { Pre- and } \\
\text { postmenopausal } \\
\text { women and men } \\
\text { with HR+, HER2- } \\
\text { ad- } \\
\text { vanced/metastatic } \\
\text { breast cancer. }\end{array}$ & 150 & $\begin{array}{l}\text { A CDK4/6 inhibitor + } \\
\text { endocrine therapy } \\
\text { versus chemotherapy }+ \\
\text { endocrine therapy }\end{array}$ & 2017 & 2022 & NCT03227328 \\
\hline FATIMA & $\begin{array}{c}\text { Premenopausal } \\
\text { women with HR+, } \\
\text { HER2- ad- } \\
\text { vanced/metastatic } \\
\text { breast cancer. }\end{array}$ & 160 & $\begin{array}{c}\text { Palbociclib + } \\
\text { exemestane }+ \text { goserelin } \\
\text { versus } \\
\text { exemestane }+ \text { goserelin } \\
\text { alone }\end{array}$ & 2019 & 2021 & NCT02917005 \\
\hline PACE & $\begin{array}{c}\text { Pre- and } \\
\text { postmenopausal } \\
\text { women and men } \\
\text { with HR+, HER2- } \\
\text { ad- } \\
\text { vanced/metastatic } \\
\text { breast cancer after } \\
\text { CDK and endocrine } \\
\text { therapy }\end{array}$ & 220 & $\begin{array}{l}\text { Palbociclib + fulvestrant } \\
\quad+\text { avelumab versus } \\
\text { Palbociclib + fulvestrant } \\
\text { versus fulvestrant alone }\end{array}$ & 2017 & 2021 & NCT03147287 \\
\hline
\end{tabular}

\section{Clinical Impact and Real-Life Data on CDK4/6 Inhibitors}

Beyond prospective, randomized, double-blind studies, multiple clinical real-life studies considering CDK4/ 6 inhibitors in MBC have been published within recent years. In real-world studies, nonrandomized heterogeneous groups of patients with different pretreatments and co-morbidities who present in the clinical routine are included and therefore the selection bias is lower [22]. Furthermore, data collection for patient subgroups who are excluded or underrepresented in randomized, controlled clinical trials is achievable. Many topics related to practical aspects of the CDK4/ 6 inhibitor therapy are still unclear, and with the rising numbers of studies, optimism exists that clear answers will be found in the future. Firstly, we do not know at what point of disease progression a CDK4/6 inhibitor therapy should be started. Considering an early relapse ( $<12$ months) as a sign of 
resistance to endocrine therapy, an addition of a CDK4/6 inhibitor is indicated in these patients $[13,23]$. However, an improved PFS was also observed in clinical trials with firstline CDK4/ 6 inhibitor therapy [24]. Despite the fact that patients having a better prognosis, especially with bone-only metastasis, usually respond well to endocrine-only therapy, there is potential for the improvement of PFS with a CDK4/6 inhibitor. Ongoing and future clinical studies will help in finding an answer to the first-/second-line question in relation to CDK4/6 inhibitors [25] (Table 2).

A recent meta-analysis showed no superiority of a chemotherapy regimen, with or without targeted agents, compared to CDK4/6-inhibitor-plus-endocrine therapy in postmenopausal patients with HR+, HER2- MBC [26]. Because of the favorable toxicity profile, CDK4/6 inhibitors should be preferred over chemotherapy in first- or second-line therapy; except in the presence of visceral crisis.

Current pooled data analyses emphasize a benefit in PFS for all analyzed subgroups of HR+, HER2- MBC patients [27,28]. The benefit occurred regardless of the combined endocrine drug (AI/fulvestrant), line of therapy, site of metastases, presence of visceral metastases, or the length of the treatment-free interval. Furthermore, there is evidence to suggest an improvement of PFS independent of age and menopausal status. However, data suggest that some subgroups of patients have a higher benefit than others, mainly in the subgroups of postmenopausal women, patients with visceral metastasis, and patients with the progression of disease under endocrine therapy (second-line therapy) [29]. Regarding the intrinsic molecular subtypes of BC, PFS is marginally pronounced in the luminal A subtype compared to the luminal B subtype in the cohort of PALOMA-2 and -3 [30].

Due to the immaturity of the OS data in most of the considered studies, the interpretation of OS improvement needs to be regarded with caution [27]. To date, we have seen statistically relevant longer OS in the few studies with abemaciclib and ribociclib, but not with palbocilicib, which only showed a positive trend [28]. Despite meta-analyses suggesting a PFS benefit for all HR+, HER2- MBC patients, it is worth considering the subgroup analyses from separate pivotal studies. As already mentioned, the group of patients with $\mathrm{HR}+, \mathrm{HER} 2-\mathrm{MBC}$ is heterogeneous, and if a subgroup analysis reveals a superior benefit, the question arises whether this subgroup has additional selection bias.

Regarding menopausal status, premenopausal women are underrepresented in most clinical studies of MBC. The MONALEESA-7 study selected premenopausal women with $\mathrm{HR}+, \mathrm{HER} 2-\mathrm{MBC}$ and revealed a significant improvement of PFS and OS in the ribocilib group (OS at 42 months of $70.2 \%$ versus $46.0 \%$ in the placebo group) [16]. PFS was shorter in patients with prior chemotherapy. No strong benefit could be observed in women with bone-only metastasis or progression > 12 months after the end of the endocrine therapy, as these patients have a significant better prognosis per se [16]. Similarly, in the MONARCH-2 trial, including pre- and postmenopausal women, patients with visceral metastases and patients with primary endocrine therapy resistance, both poor prognostic factors, had a stronger OS effect [17]. Interestingly, an analysis from the PALOMA-3 trial showed an improved OS in the subgroup of patients with endocrine-sensitive tumors, as well as in the subgroup without prior chemotherapy in the MBC status [31]. Patients with metastasis of the central nervous system may benefit from abemaciclib, as it penetrates the blood-brain barrier. As patients with CNS metastasis were excluded from most phase III CDK4/ 6 inhibitor trials, a clear recommendation cannot be given. However, a current study revealed potential benefit for patients with $\mathrm{HR}+, \mathrm{HER} 2-\mathrm{MBC}$ with brain metastasis who were naïve to a CDK4/6 inhibitor therapy [32].

We still know far too little about predictive biomarkers for CDK4/6 inhibitors, and therefore the data and analyses only partially explain the differing benefits of MBC patient subgroups. As the relevance of individualized medicine increases, studies considering the complexity of patient-related and tumor-related factors are crucially needed [33,34] (Table 2). 


\section{Adverse Events, Quality of Life, and Non-Compliance under CDK4/6 Inhibitors}

Prolongated PFS and OS under palliative therapy always need to be balanced between toxicity and the risk of adverse events (AEs) on the one hand, and the potential benefit of less morbidity and gained lifetime on the other hand. The tolerability of CDK4/ 6 inhibitors is usually acceptable and manageable with dose modification and side effect treatment. Minor AEs are reported in most patients (60-80\%) under CDK4/ 6 inhibitor therapy, resulting in a dose reduction in every third patient $[35,36]$. Serious AEs (SAEs; grade $3 / 4$ ) that lead to discontinuation are reported in up to $12 \%$ of patients [36]. Hematological toxicities are frequent, especially in palbociclib and ribociclib, leading to neutropenia, anemia, and thrombocytopenia [37]. Compared to most chemotherapy regimens, toxicity is lower, and AEs are manageable in most cases with early interventions. Fatigue, diarrhea, and nausea are more often reported under abemaciclib intake, leading to a significant higher rate of treatment discontinuation [38]. A pronunciation of gastrointestinal AEs is observed in combination with fulvestrant compared to AI. Less frequent AEs are hepatotoxicity, venous thromboembolic events, QT-interval prolongation, increased serum creatinine, and pneumonitis [38]. The high risk of SAE should be especially considered in long-term treatment. As all three CDK4/6 inhibitors showed a comparable improvement of PFS, treatment choices can consider the drug with the most reasonable side effect profile for the individual patient [26]. This can be recommended as long as mature OS data for the single drugs are not present. In case of the proven superiority of one or two CDK4/6 inhibitors, this up-front recommendation will change.

Fortunately, the measurement of patient-reported outcome (PRO) has become an important tool in prospective, randomized trials. However, quality-of-life (QOL) data in CDK4/6 inhibitors are still limited. The available data suggest a satisfactory-to-good QOL in patients with $\mathrm{MBC}$ and CDK4/6 inhibitor therapy, even when experiencing AEs [35,39]. In the setting of the PALOMA-2 trial, decreasing QOL was mainly associated with progressive disease and a non-response [40]. Beyond clinical trials, we observe noncompliance with palliative systemic therapy in a notable group of unselected patients with MBC [41]. However, there has been no meta-analysis of compliance in CDK4/ 6 inhibitor therapy, and real-life clinical studies report disruption of the therapy in $11 \%$ and non-adherence in more than $20 \%$ of cases, without considering patients with initial therapy refusal [42]. The reasons for non-compliance and non-adherence are heterogeneous and closely based on the individual patient's experience and background. Objectively "light" side effects might be intolerable in some patients, whereas other patients are highly motivated to continue therapy even under SAE. In understanding the patient's individual needs, support and compliance can be improved.

\section{Resistance to CDK4/6 Inhibitors}

CDK4/ 6 inhibitor therapy can prolong the time of stable disease in HR+ MBC. However, primary resistance to CDK4/6 inhibitors occurs in about $15-30 \%$ of cases, and at some point of the therapy, almost all patients develop a progressive disease, which reflects an acquired resistance to CDK4/ 6 inhibitors [43]. Interestingly, a therapeutic switch to abemaciclib in patients who progress under other CDK4/ 6 inhibitors was beneficial for a subgroup of patients with HR+, HER2- MBC [44]. As is the case in other clinical studies, potential predictive biomarkers are missing. Preclinical and clinical studies suggest variable mechanisms of tumor cell resistance due to several tumor suppressor gene mutations, but without evident predictive value [45]. PIK3CA and ESR1 mutations can be detected in circulating tumor DNA in up to every third patient with HR+, HER2- MBC [46]. However, several studies, such as the PALOMA-3 trial, did not reveal a predictive value of the CDK4/ 6 inhibitor response [43]. Whole-exome sequencing of 59 tumors suggests an association of several mutations (loss of RB1, loss of estrogen receptor, activating alterations in AKT1, RAS, AURKA, CCNE2, ERBB2, and FGFR2) to CDK4/ 6 inhibitor resistance, but still without predictive value [47]. Interestingly, the prevalence of $B C$ cells with estrogen receptor 1 (ESR1) mutations is much higher in patients with MBC who received AI (up 
to $40 \%$ versus $1 \%$ in MBC patients without prior ET). Despite a clear association between ESR1 mutations and endocrine resistance, data about predicting the response to AI and/or CDK4/6 inhibitors are contradictory [48]. Further studies are warranted to clarify whether the detection of ESR1 mutations may influence clinical decisions and the indication of CDK4/6 inhibitors in the metastatic or adjuvant setting [49]. Recently, tumor mutations of the KRAS protein that induce cyclin D1 overexpression have been associated with acquired loss of responsiveness [50]. As in the cited study where circulating tumor cells in the plasma were analyzed, liquid biopsy could be a potential clinical approach to predict resistance to CDK4/6 inhibitors. It is assumed that the complex mechanism of acquired resistance is not yet fully understood. The only predictive biomarker for CDK4/6 inhibitors remains a positive estrogen receptor status; further biomarkers that predict sensitivity for or resistance to CDK4/6 inhibitors are still missing [27,34,51].

\section{Alternative Therapeutic Approaches for Patients with CDK4/6 Inhibitor Resistance}

On a molecular level, the CDK4/6 and PI3K-mTOR pathways interfere with the cell signaling and division processes. Both pathways are closely related to each other, as a hyperactivated PI3K-mTOR pathway increases cyclin D levels [52]. Physiologically, these pathways regulate cell metabolism, survival, proliferation, and growth in multicellular organisms [53]. Deregulation of the PI3K/AKT/mTOR pathway caused by PIK3CAactivating mutations can be detected in almost every third patient with $\mathrm{BC}$, and in about $40 \%$ of patients with HR+, HER2- BC [54,55]. When detected in early HR+ BC, these mutations are associated with improved disease-free survival. In patients with advanced and metastatic $\mathrm{HR}+\mathrm{BC}$, increasing resistance to endocrine therapy and a lower response to chemotherapy was observed when PIK3CA-activating mutations were present [56-58].

\subsection{PI3K Inhibitors}

The earlier BELLE trial observed a therapeutic benefit from buparlisib, a PI3K inhibitor without isoform specificity, but with high off-target side effects and without clinical relevance [59]. More specific PI3K inhibitors promise to reduce off-target toxicities; however, taselisib, a PI3Kß-specific inhibitor, still showed an insufficient safety profile and only a modest benefit [60]. The first approved PIK3 inhibitor, alpelisib, selectively inhibits the alpha isoform of PI3K that is encoded by PIK3CA mutations. In the phase III trial SOLAR-1, alpelisib improved the PFS in the cohort with PIK3CA-mutated cancer (11.7 months in the alpelisib-fulvestrant group versus 5.7 months in the placebo-fulvestrant group) [61]. This was especially true for the small group of patients who received previous therapy with a CDK4/6 inhibitor plus AI [61]. These findings are emphasized by recently published interim results from the BYLieve trial with a PFS of 50.4\% after six months [5]. The observed cohort received alpelisib after disease progression on or after a CDK4/6 inhibitor plus AI. However, the number of patients was limited, and a comparator group was lacking. Discontinuation due to AE was reported in every fifth patient. Overall, the safety profile in the BYLieve trial was tolerable under careful AE monitoring, especially of hyperglycemia. Alpelisib is a specific PI3K inhibitor that targets the catalytic alpha-unit of PI3K, but as these drugs are ATP-competitive, they also affect a major signaling cell pathway [62]. This mechanism of action explains concentration-dependent and frequent severe AEs. Skin rash, diarrhea, alopecia, nausea, and hyperglycemia are the most common side effects of alpelisib [61]. Threatening hyperglycemia and ketoacidosis have been reported in less than $1 \%$ of cases but this remains a worrisome $\mathrm{AE}$ that requires close monitoring during drug administration [63]. Obviously, alpelisib should be restrictively indicated in patients with diabetes. The patient-reported outcome in the SOLAR-1 study showed no statistical difference between arms. Despite this, it is an important consideration that patients participating a phase III trial are carefully selected and monitored; these results support the manageable risk profile of alpelisib [64]. Only very limited real-world data on alpelisib in the clinical routine are available so far. Recently published results emphasized the importance of careful interdisciplinary surveillance and patient education under alpelisib therapy [65]. 
Stable disease was significantly improved in patients with $\mathrm{HR}+$, PIK3CA-mutated $\mathrm{ABC}$ who previously experienced progression on or after CDK4/6 inhibitor plus AI [5]. CDK4/6 inhibitors sensitize cells with resistance to PI3K inhibitor in vivo [52]. On the other hand, a clinical study suggests cross-resistance to PI3K inhibitors of tumors previously treated with CDK4/6 inhibitors, which is probably based on the loss of PTEN [45]. In patients with a PIK3CA-mutated HER2+ BC, the therapy combination with trastuzumab was limited by severe gastrointestinal toxicity [66]. Likewise, a combination with chemotherapy in patients with PIK3CA-mutated TNBC has no clinical relevance due to the toxicity profile [67]. As already emphasized, PIK3CA mutations cannot act as a biomarker of response or resistance to CDK4/6 inhibitors. However, there is evidence to suggest that PIK3CA mutations are acquired during endocrine treatment alone, as well as during CDK4/6 inhibitor plus endocrine therapy [68]. Interestingly, an association between reduced CDK4/6 inhibitor sensitivity and PI3K mutations detected in liquid biopsy was observed in a pilot study [69]. The SOLAR-1 trial, as well as the SANDPIPER trial, showed no relevant benefit in patients without PIK3CA-mutated MBC [61,70]. In HR+, HER2- MBC patients with resistance to CDK4/6 inhibitors plus endocrine treatment, PIK3CA mutation testing on tumor tissue or circulating tumor cells is justified to select patients who could potentially benefit from alpelisib [71]. To date, no predictive markers have been found that indicate a clinical response to PI3K inhibitors in the subgroup of patients with PIK3CA-activating mutations [52]. Multiple ongoing and future clinical trials are expected to clarify the relevance of alpelisib and potentially other PI3K inhibitors in the clinical routine (Table 3).

\subsection{Everolimus}

Endocrine resistance is more frequent in tumors with a hyperactivated PAM pathway, which can be caused by mutations of the PI3K gene and AKT activation [72]. The mammalian target of the rapamycin (mTOR) inhibitor everolimus was the first targeted drug in patients with endocrine resistance and showed a prolonged PFS in patients with HR+, HER2- MBC. Moreover, it has a positive effect on bone metabolism and delays bone metastasis progression [73]. An important issue in everolimus therapy is the toxicity profile, which is less favorable compared to that of CDK4/6 inhibitors. The most frequent AEs are hyperglycemia, stomatitis, anemia, dyspnea, and fatigue and this led to dose reduction in two-thirds of patients and a therapy discontinuation in more than $12 \%$ in several studies [74]. However, a network analysis showed a similar significant improvement of PFS in studies with CDK4/6 inhibitor- based combinations compared with studies with everolimus plus exemestane; no randomized trial of both these combinations has been performed [75]. An improvement of OS was observed in randomized phase III studies with everolimus, but without statistical relevance [76]. In contrast, a clearly relevant benefit was demonstrated in recent $\mathrm{CDK} 4 / 6$ inhibitor trials [6,16]. It is notable that in the BOLERO-2 study, the benefit from everolimus was not influenced by the presence of PIK3CA tumor mutations [77]. A recent retrospective comparative analysis showed a higher efficacy of everolimus plus exemestane in patients with prior CDK4/6 inhibitor plus endocrine therapy than in patients with prior endocrine therapy alone [78]. A potential selection bias caused by patients with CDK4/6 inhibitor resistance due to PIK3CA mutations who benefit from a second- or third-line therapy with everolimus has to be considered. However, everolimus remains a second- or third-line treatment option in patients with $\mathrm{HR}+, \mathrm{HER} 2-\mathrm{MBC}$. This is especially true for patients with PIK3CA mutations who show a disease progression on PI3K inhibitor therapy or who experience contraindications to PI3K inhibitors [78].

\subsection{AKT Inhibitors}

A further option for patients with resistance to CDK4/6 inhibitors could be treatment with AKT inhibitors, as recently shown by results from the FAKTION trial [79]. Capivasertib, a selective inhibitor of the serine/threonine kinase AKT, plus fulvestrant showed a significant improvement of PFS compared to placebo plus fulvestrant in patients with 
aromatase inhibitor- resistant MBC. However, long-term outcomes and phase III study results with a larger number of patients are still pending.

Table 3. Selected ongoing trials with PI3K inhibitors in patients with breast cancer.

\begin{tabular}{|c|c|c|c|c|c|c|}
\hline Clinical Trial & Patient Selection & $\begin{array}{c}\text { Estimated } \\
\text { Enrollment }(n)\end{array}$ & $\begin{array}{l}\text { Therapeutic } \\
\text { Regimen }\end{array}$ & $\begin{array}{c}\text { Study Start } \\
\text { Year }\end{array}$ & $\begin{array}{c}\text { Estimated } \\
\text { Completion Year }\end{array}$ & $\begin{array}{l}\text { Clinical Trial } \\
\text { Information }\end{array}$ \\
\hline $\begin{array}{l}\text { Alpelisib with } \\
\text { endocrine therapy } \\
\text { following progression } \\
\text { on endocrine therapy }\end{array}$ & $\begin{array}{c}\text { Pre- and } \\
\text { postmenopausal } \\
\text { women and men with } \\
\text { PIK3CA mutant HR+, } \\
\text { HER2- MBC }\end{array}$ & 44 & $\begin{array}{c}\text { Alpelisib }+ \\
\text { aromatase inhibitor } \\
\text { or fulvestrant }\end{array}$ & 2021 & 2024 & NCT04762979 \\
\hline $\begin{array}{c}\text { Alpelisib with } \\
\text { trastuzumab and } \\
\text { pertuzumab as } \\
\text { maintenance therapy }\end{array}$ & $\begin{array}{c}\text { Pre- and } \\
\text { postmenopausal } \\
\text { women and men with } \\
\text { HER2+, PIK3CA } \\
\text { mutant ABC }\end{array}$ & 588 & $\begin{array}{c}\text { Alpelisib + } \\
\text { trastuzumab + } \\
\text { pertuzumab versus } \\
\text { placebo + } \\
\text { trastuzumab + } \\
\text { pertuzumab }\end{array}$ & 2020 & 2025 & NCT04208178 \\
\hline $\begin{array}{l}\text { Inavolisib in patients } \\
\text { with PIK3CA-mutant, } \\
\text { HR+, HER2- locally } \\
\text { advanced or } \\
\text { metastatic breast } \\
\text { cancer }\end{array}$ & $\begin{array}{c}\text { Pre- and } \\
\text { postmenopausal } \\
\text { women and men with } \\
\text { HR+, HER2-- } \\
\text { PIK3CA mutant } \\
\text { A/MBC }\end{array}$ & 400 & $\begin{array}{c}\text { Inavolisib + } \\
\text { palbociclib + } \\
\text { fulvestrant versus } \\
\text { placebo + } \\
\text { palbociclib + } \\
\text { fulvestrant }\end{array}$ & 2020 & 2025 & NCT04191499 \\
\hline $\begin{array}{c}\text { Alpelisib + } \\
\text { nab-paclitaxel in } \\
\text { subjects with } \\
\text { advanced TNBC who } \\
\text { carry either a PIK3CA } \\
\text { mutation or have } \\
\text { PTEN loss (EPIK-B3) }\end{array}$ & $\begin{array}{c}\text { Pre- and } \\
\text { postmenopausal } \\
\text { women and men with } \\
\text { advanced TNBC with } \\
\text { PIK3CA mutation or } \\
\text { PTEN loss }\end{array}$ & 566 & $\begin{array}{c}\text { Alpelisib + } \\
\text { nab-paclitaxel } \\
\text { versus } \\
\text { placebo + } \\
\text { nab-paclitaxel }\end{array}$ & 2020 & 2023 & NCT04251533 \\
\hline PERSEVERE & $\begin{array}{c}\text { Pre- and } \\
\text { postmenopausal } \\
\text { women and men with } \\
\text { post-neoadjuvant } \\
\text { residual TNBC }\end{array}$ & 197 & $\begin{array}{l}\text { Assignment due to } \\
\text { the genomic target } \\
\text { of ctDNA: } \\
\text { talazoparib + } \\
\text { capecitabine; } \\
\text { atezolizumab + } \\
\text { capecitabine; } \\
\text { inavolisib + } \\
\text { capecitabine; } \\
\text { talazoparib + } \\
\text { atezolizumab + } \\
\text { capecitabine }\end{array}$ & 2021 & 2024 & NCT04849364 \\
\hline
\end{tabular}

\section{Conclusions and Perspective}

With the goal of overcoming endocrine resistance in $\mathrm{HR}+\mathrm{MBC}$, the connecting CDK and PI3K/AKT/mTOR pathways were revealed as key points for targeted therapies. As multiple studies have shown a clear benefit of CDK4/6 inhibitors, current guidelines recommend this therapy in patients with MBC $[80,81]$. The toxicity profile of CDK4/6 inhibitors is favorable to chemotherapy. In patients with primary or acquired resistance to CDK4/ 6 inhibitors, the earlier-approved everolimus remains an alternative. In the presence of PIK3CA-mutated BC cells, PI3K inhibitors can be indicated. However, data showing a benefit in overall survival are still missing.

The role of targeted therapy in the adjuvant setting is still unclear and is a topic of ongoing studies (Table 4). The PALLAS study did not show a benefit of adding palbociclib to adjuvant endocrine therapy [82]. Similarly, beneficial results were missing in patients with residual disease of HR+, HER2 - BC after NACT (PENELOPE-B trial) [83], whereas in patients with high-risk $B C$ in the adjuvant setting, PFS was improved when adding abemaciclib to endocrine therapy [84]. Likewise, in high-risk BC patients with PIK3CA-mutated tumors, there is a benefit associated with PI3K inhibitors in a neoadju- 
vant approach. The LORELEI study demonstrated a significantly higher response rate in patients treated with teselisib and letrozole versus placebo and letrozole [85].

Table 4. Selected ongoing trials with CDK4/6 inhibitors in patients with HR+, HER2 - breast cancer in the adjuvant setting.

\begin{tabular}{|c|c|c|c|c|c|c|}
\hline Clinical Trial & Patient Selection & $\begin{array}{c}\text { Estimated } \\
\text { Enrollment }(n)\end{array}$ & $\begin{array}{c}\text { Therapeutic } \\
\text { Regimen }\end{array}$ & $\begin{array}{c}\text { Study Start } \\
\text { Year }\end{array}$ & $\begin{array}{c}\text { Estimated } \\
\text { Completion Year }\end{array}$ & $\begin{array}{l}\text { Clinical Trial } \\
\text { Information }\end{array}$ \\
\hline NATALEE & $\begin{array}{c}\text { Pre- and } \\
\text { postmenopausal } \\
\text { women and men }\end{array}$ & 5000 & $\begin{array}{l}\text { Ribociclib + } \\
\text { endocrine } \\
\text { therapy versus } \\
\text { endocrine } \\
\text { therapy alone }\end{array}$ & 2018 & 2026 & NCT03701334 \\
\hline APPALACHES & $\begin{array}{l}\text { Women or men } \\
70 \text { years and } \\
\text { older for whom } \\
\text { chemotherapy is } \\
\text { indicated }\end{array}$ & 366 & $\begin{array}{c}\text { Palbociclib }+ \\
\text { endocrine } \\
\text { therapy } \\
\text { versus } \\
\text { chemotherapy + } \\
\text { endocrine } \\
\text { therapy }\end{array}$ & 2019 & 2025 & NCT03609047 \\
\hline POLAR & $\begin{array}{c}\text { Pre- and } \\
\text { postmenopausal } \\
\text { women or men } \\
\text { with } \\
\text { local/regional } \\
\text { recurrence of BC }\end{array}$ & 400 & $\begin{array}{l}\text { Palbociclib + } \\
\text { endocrine } \\
\text { therapy versus } \\
\text { endocrine } \\
\text { therapy alone }\end{array}$ & 2019 & 2024 & NCT03820830 \\
\hline POETIC-A & $\begin{array}{l}\text { Postmenopausal } \\
\text { woman with high } \\
\text { 5-year risk of } \\
\text { relapse }\end{array}$ & 2500 & $\begin{array}{l}\text { Abemaciclib + } \\
\text { endocrine } \\
\text { therapy versus } \\
\text { endocrine } \\
\text { therapy alone }\end{array}$ & 2020 & 2026 & NCT04584853 \\
\hline LEADER & $\begin{array}{c}\text { Pre- and } \\
\text { postmenopausal } \\
\text { women }\end{array}$ & 120 & $\begin{array}{l}\text { Ribociclib + } \\
\text { endocrine } \\
\text { therapy versus } \\
\text { endocrine } \\
\text { therapy alone }\end{array}$ & 2017 & 2022 & NCT03285412 \\
\hline SAFIA & $\begin{array}{c}\text { Pre- and } \\
\text { postmenopausal } \\
\text { women in the } \\
\text { neoadjuvant } \\
\text { setting }\end{array}$ & 400 & $\begin{array}{c}\text { Palbociclib + } \\
\text { fulvestrant } \\
\text { versus placebo } \\
+ \text { fulvestrant } \\
\text { alone }\end{array}$ & 2018 & 2023 & NCT03447132 \\
\hline
\end{tabular}

Our review provides updates on the feasible current targeted therapies in the clinical practice of HR+, HER2- MBC. In summary, adequate patient selection is crucial for therapeutic efficacy. We believe that remaining questions will be answered within the coming years, when selection criteria on a clinical and molecular basis are fully understood.

\section{Strengths and Limitations}

Our review has some limitations. We exclusively considered publications in English. As we included results from real-life studies as well as data from observational studies with patient-reported outcomes, our review is not appropriate for a meta-analysis. However, besides the up-to-date summery of OS and PFS, our review also considers clinically relevant studies about toxicity and quality of life in targeted therapy in patients with HR+ MBC. It discusses the indications, expectations, and limitations of targeted therapy and may help the oncologist to select patients under real-life conditions. 
Author Contributions: Conceptualization, V.B.-R. and C.E.; methodology, C.E.; validation V.B.-R. and C.E.; writing C.E.; review and editing V.B.-R. and C.E.; supervision V.B.-R. All authors have read and agreed to the published version of the manuscript.

Funding: This research received no external funding.

Conflicts of Interest: The authors declare no conflict of interest.

\section{References}

1. Early Breast Cancer Trialists' Collaborative Group (EBCTCG). Effects of chemotherapy and hormonal therapy for early breast cancer on recurrence and 15-year survival: An overview of the randomised trials. Lancet 2005, 365, 1687-1717. [CrossRef]

2. Anderson, W.F.; Chatterjee, N.; Ershler, W.B.; Brawley, O.W. Estrogen receptor breast cancer phenotypes in the Surveil-lance, Epidemiology, and End Results database. Breast Cancer Res. Treat. 2002, 76, 27-36. [CrossRef]

3. Gradishar, W.J.; Anderson, B.O.; Abraham, J.; Aft, R.; Agnese, D.; Allison, K.H.; Blair, S.L.; Burstein, H.J.; Dang, C.; Elias, A.D.; et al. Breast Cancer, Version 3.2020, NCCN Clinical Practice Guidelines in Oncology. J. Natl. Compr. Cancer Netw. 2020, 18, 452-478. [CrossRef] [PubMed]

4. Caswell-Jin, J.; Plevritis, S.K.; Tian, L.; Cadham, C.; Xu, C.; Stout, N.K.; Sledge, G.W.; Mandelblatt, J.S.; Kurian, A.W. Change in Survival in Metastatic Breast Cancer with Treatment Advances: Meta-Analysis and Systematic Review. JNCI Cancer Spectr. 2018, 2, pky062. [CrossRef] [PubMed]

5. Rugo, H.S.; Lerebours, F.; Ciruelos, E.; Drullinsky, P.; Ruiz-Borrego, M.; Neven, P. Alpelisib plus fulvestrant in PIK3CA-mutated, hormone receptor-positive advanced breast cancer after a CDK4/6 inhibitor (BYLieve): One cohort of a phase 2, multicentre, open-label, non-comparative study. Lancet Oncol. 2021, 22, 489-498. [CrossRef]

6. Slamon, D.J.; Neven, P.; Chia, S.; Fasching, P.A.; De Laurentiis, M.; Im, S.-A.; Petrakova, K.; Bianchi, G.V.; Esteva, F.; Martín, M.; et al. Overall Survival with Ribociclib plus Fulvestrant in Advanced Breast Cancer. N. Engl. J. Med. 2020, 382, 514-524. [CrossRef]

7. Henley, S.A.; Dick, F.A. The retinoblastoma family of proteins and their regulatory functions in the mammalian cell di-vision cycle. Cell Div. 2012, 7, 10. [CrossRef]

8. Goel, S.; DeCristo, M.J.; McAllister, S.S.; Zhao, J.J. CDK4/6 Inhibition in Cancer: Beyond Cell Cycle Arrest. Trends Cell Biol. 2018, 28, 911-925. [CrossRef]

9. Klein, M.E.; Kovatcheva, M.; Davis, L.E.; Tap, W.D.; Koff, A. CDK4/6 inhibitors: The mechanism of action may not be as simple as once thought. Cancer Cell 2018, 34, 9-20. [CrossRef] [PubMed]

10. Shah, M.; Nunes, M.R.; Stearns, V. CDK4/6 Inhibitors: Game Changers in the Management of Hormone Receptor-Positive Advanced Breast Cancer? Oncol. Williston Park N 2018, 32, 216-222.

11. Slamon, D.J.; Neven, P.; Chia, S.; Fasching, P.A.; De Laurentiis, M.; Im, S.A.; Petrakova, K.; Bianchi, G.V.; Esteva, F.J.; Martin, M.; et al. Phase III Randomized Study of Ribociclib and Fulvestrant in Hormone Receptor-Positive, Human Epidermal Growth Factor Receptor 2-Negative Advanced Breast Cancer: MONALEESA-3. J. Clin. Oncol. 2018, 36, 2465-2472. [CrossRef] [PubMed]

12. Hamilton, E.; Cortes, J.; Ozyilkan, O.; Chen, S.-C.; Petrakova, K.; Manikhas, A.; Jerusalem, G.; Hegg, R.; Huober, J.; Chapman, S.C.; et al. nextMONARCH: Abemaciclib Monotherapy or Combined with Tamoxifen for Metastatic Breast Cancer. Clin. Breast Cancer 2020, 21, 181-190.e2. [CrossRef] [PubMed]

13. Li, J.; Huo, X.; Zhao, F.; Ren, D.; Ahmad, R.; Youan, X.; Du, F.; Zhao, J. Association of Cyclin-Dependent Kinases 4 and 6 In-hibitors With Survival in Patients With Hormone Receptor-Positive Metastatic Breast Cancer: A Systematic Review and Meta-analysis. JAMA Netw. Open 2020, 3, e2020312. [CrossRef] [PubMed]

14. Kristensen, K.B.; Thomsen, I.M.N.; Berg, T.; Kodahl, A.R.; Jensen, A.B. Dose modifications of ribociclib and endocrine therapy for treatment of ER+ HER2- metastatic breast cancer. Breast Cancer Res. Treat. 2021, 188, 799-809. [CrossRef] [PubMed]

15. Denduluri, N.; Lyman, G.H.; Wang, Y.; Morrow, P.K.; Barron, R.; Patt, D.; Bhowmik, D.; Li, X.; Bhor, M.; Fox, P.; et al. Chemotherapy Dose Intensity and Overall Survival Among Patients with Advanced Breast or Ovarian Cancer. Clin. Breast Cancer 2018, 18, 380-386. [CrossRef] [PubMed]

16. Im, S.-A.; Lu, Y.-S.; Bardia, A.; Harbeck, N.; Colleoni, M.; Franke, F.; Chow, L.; Sohn, J.; Lee, K.-S.; Campos-Gomez, S.; et al. Overall Survival with Ribociclib plus Endocrine Therapy in Breast Cancer. N. Engl. J. Med. 2019, 381, 307-316. [CrossRef] [PubMed]

17. Sledge, G.W.; Toi, M.; Neven, P.; Sohn, J.; Inoue, K.; Pivot, X.; Burdaeva, O.; Okera, M.; Masuda, N.; Kaufman, P.A.; et al. The Effect of Abemaciclib Plus Fulvestrant on Overall Survival in Hormone Receptor-Positive, ERBB2-Negative Breast Cancer That Progressed on Endocrine Therapy-MONARCH 2: A Randomized Clinical Trial. JAMA Oncol. 2020, 6, 116-124. [CrossRef] [PubMed]

18. Turner, N.C.; Slamon, D.J.; Ro, J.; Bondarenko, I.; Im, S.-A.; Masuda, N.; Colleoni, M.; DeMichele, A.; Loi, S.; Verma, S.; et al. Overall Survival with Palbociclib and Fulvestrant in Advanced Breast Cancer. N. Engl. J. Med. 2018, 379, 1926-1936. [CrossRef]

19. Goel, S.; Wang, Q.; Watt, A.C.; Tolaney, S.M.; Dillon, D.A.; Li, W.; Ramm, S.; Palmer, A.C.; Yuzugullu, H.; Varadan, V.; et al. Overcoming Therapeutic Resistance in HER2-Positive Breast Cancers with CDK4/6 Inhibitors. Cancer Cell 2016, $29,255-269$. [CrossRef] 
20. Tolaney, S.M.; Wardley, A.M.; Zambelli, S.; Hilton, J.F.; Troso-Sandoval, T.A.; Ricci, F.; Im, S.-A.; Kim, S.-B.; Johnston, S.R.; Chan, A.; et al. Abemaciclib plus trastuzumab with or without fulvestrant versus trastuzumab plus standard-of-care chemotherapy in women with hormone receptor-positive, HER2-positive advanced breast cancer (monarcHER): A randomised, open-label, phase 2 trial. Lancet Oncol. 2020, 21, 763-775. [CrossRef]

21. Cretella, D.; Fumarola, C.; Bonelli, M.; Alfieri, R.; La Monica, S.; Digiacomo, G.; Cavazzoni, A.; Galetti, M.; Generali, D.; Petronini, P.G. Pre-treatment with the CDK4/6 inhibitor palbociclib improves the efficacy of paclitaxel in TNBC cells. Sci. Rep. 2019, 9, 13014 .

22. Di Maio, M.; Perrone, F.; Conte, P. Real-World Evidence in Oncology: Opportunities and Limitations. Oncol. 2019, 25, e746-e752. [CrossRef] [PubMed]

23. Cardoso, F.; Senkus, E.; Costa, A.; Papadopoulos, E.; Aapro, M.; André, F.; Harbeck, N.; Aguilar Lopez, B.; Barrios, C.H.; Bergh, J.; et al. 4th ESO-ESMO International Consensus Guidelines for Advanced Breast Cancer (ABC 4). Ann. Oncol. 2018, 29, 1634-1657. [CrossRef] [PubMed]

24. Rossi, V.; Berchialla, P.; Giannarelli, D.; Nistico, C.; Ferretti, G.; Gasparro, S.; Russillo, M.; Gatania, G.; Vigna, L.; Mancusi, R.L.; et al. Should All Patients With HR-Positive HER2-Negative Metastatic Breast Cancer Receive CDK 4/6 Inhibitor As First-Line Based Therapy? A Network Meta-Analysis of Data from the PALOMA 2, MONALEESA 2, MONALEESA 7, MON-ARCH 3, FALCON, SWOG and FACT Trials. Cancers 2019, 11, 1661. [CrossRef] [PubMed]

25. Van Ommen-Nijhof, A.; Konings, I.R.; Van Zeijl, C.J.J.; Uyl-de Groot, C.A.; Van der Noort, V.; Jager, A.; Sonke, G.S. Selecting the optimal position of CDK4/ 6 inhibitors in hormone receptor-positive advanced breast cancer-The SONIA study: Study protocol for a randomized controlled trial. BMC Cancer 2018, 18, 1146. [CrossRef]

26. Giuliano, M.; Schettini, F.; Rognoni, C.; Milani, M.; Jerusalem, G.; Bachelot, T.; De Laurentiis, M.; Thomas, G.; De Placido, P.; Arpino, G.; et al. Endocrine treatment versus chemotherapy in postmenopausal women with hormone receptor-positive, HER2-negative, metastatic breast cancer: A systematic review and network meta-analysis. Lancet Oncol. 2019, 20, 1360-1369. [CrossRef]

27. Gao, J.J.; Cheng, J.; Bloomquist, E.; Sanchez, J.; Wedam, S.B.; Singh, H.; Amiri-Kordestani, L.; Ibrahim, A.; Sridhara, R.; Goldberg, K.B.; et al. CDK4/6 inhibitor treatment for patients with hormone receptor-positive, HER2-negative, advanced or metastatic breast cancer: A US Food and Drug Administration pooled analysis. Lancet Oncol. 2020, 21, 250-260. [CrossRef]

28. Piezzo, M.; Chiodini, P.; Riemma, M.; Cocco, S.; Caputo, R.; Cianniello, D.; Di Gioia, G.; Di Lauro, V.; Di Rella, F.; Fusco, G.; et al. Progression-Free Survival and Overall Survival of CDK 4/6 Inhibitors Plus Endocrine Therapy in Metastatic Breast Cancer: A Systematic Review and Meta-Analysis. Int. J. Mol. Sci. 2020, 21, 6400. [CrossRef]

29. Schettini, F.; Giuliano, M.; Giudici, F.; Conte, B.; De Placido, P.; Venturini, S.; Rognoni, C.; Di Leo, A.; Locci, M.; Jerusalem, G.; et al. Endocrine-Based Treatments in Clinically-Relevant Subgroups of Hormone Receptor-Positive/HER2-Negative Meta-static Breast Cancer: Systematic Review and Meta-Analysis. Cancers 2021, 13, 1458.

30. Finn, R.S.; Cristofanilli, M.; Ettl, J.; Gelmon, K.A.; Colleoni, M.; Giorgetti, C.; Gauthier, E.; Liu, Y.; Lu, D.R.; Zhang, Z.; et al. Treatment effect of palbociclib plus endocrine therapy by prognostic and intrinsic subtype and biomarker analysis in pa-tients with bone-only disease: A joint analysis of PALOMA-2 and PALOMA-3 clinical trials. Breast Cancer Res. Treat. 2020, 184, 23-35. [CrossRef]

31. Rugo, H.; Cristofanilli, M.; Loibl, S.; Harbeck, N.; Demichele, A.; Iwata, H.; Park, Y.H.; Brufsky, A.; Theall, K.P.; Huang, X.; et al. Predictors of efficacy in patients with hormone receptor-positive/ human epidermal growth factor receptor 2-negative advanced breast cancer (HR+/HER2- ABC): Subgroup analyses of PALOMA-3. Eur. J. Cancer 2020, 138, S7-S8. [CrossRef]

32. Tolaney, S.M.; Sahebjam, S.; Le Rhun, E.; Bachelot, T.; Kabos, P.; Awada, A.; Yardley, D.; Chan, A.; Conte, P.; Diéras, V.; et al. A Phase II Study of Abemaciclib in Patients with Brain Metastases Secondary to Hormone Receptor-Positive Breast Cancer. Clin. Cancer Res. 2020, 26, 5310-5319. [CrossRef] [PubMed]

33. Roncato, R.; Angelini, J.; Pani, A.; Cecchin, E.; Sartore-Bianchi, A.; Siena, S.; De Mattia, E.; Scaglione, F.; Toffoli, G. CDK4/6 Inhibitors in Breast Cancer Treatment: Potential Interactions with Drug, Gene, and Pathophysiological Conditions. Int. J. Mol. Sci. 2020, 21, 6350. [CrossRef] [PubMed]

34. Hlevnjak, M.; Schulze, M.; Elgaafary, S.; Fremd, C.; Michel, L.; Beck, K.; Pfütze, K.; Richter, D.; Wolf, S.; Horak, P.; et al. CATCH: A Prospective Precision Oncology Trial in Metastatic Breast Cancer. JCO Precis. Oncol. 2021, 5, 676-686. [CrossRef]

35. Richardson, D.; Zhan, L.; Mahtani, R.; McRoy, L.; Mitra, D.; Reynolds, M.; Odom, D.; Hollis, K.; Kaye, J.A.; Jones, C.; et al. A prospective observational study of patient-reported functioning and quality of life in advanced and metastatic breast cancer utilizing a novel mobile application. Breast Cancer Res. Treat. 2021, 187, 113-124. [CrossRef]

36. Guo, L.; Hu, Y.; Chen, X.; Li, Q.; Wei, B.; Ma, X. Safety and efficacy profile of cyclin-dependent kinases 4/6 inhibitor palbo-ciclib in cancer therapy: A meta-analysis of clinical trials. Cancer Med. 2019, 8, 1389-1400. [CrossRef]

37. Desnoyers, A.; Nadler, M.B.; Kumar, V.; Saleh, R.; Amir, E. Comparison of treatment-related adverse events of different Cyclindependent kinase 4/6 inhibitors in metastatic breast cancer: A network meta-analysis. Cancer Treat. Rev. 2020, $90,102086$. [CrossRef]

38. Spring, L.M.; Wander, S.A.; Andre, F.; Moy, B.; Turner, N.C.; Bardia, A. Cyclin-dependent kinase 4 and 6 inhibitors for hor-mone receptor-positive breast cancer: Past, present, and future. Lancet 2020, 395, 817-827. [CrossRef] 
39. Fasching, P.A.; Beck, J.T.; Chan, A.; De Laurentiis, M.; Esteva, F.J.; Jerusalem, G.; Neven, P.; Pivot, X.; Bianchi, G.V.; Martin, M.; et al. Ribociclib plus fulvestrant for advanced breast cancer: Health-related quality-of-life analyses from the MONALEESA-3 study. Breast 2020, 54, 148-154. [CrossRef]

40. Rugo, H.; Diéras, V.; Gelmon, K.; Finn, R.; Slamon, D.; Martin, M.; Neven, P.; Shparyk, Y.; Mori, A.; Lu, D.; et al. Impact of palbociclib plus letrozole on patient-reported health-related quality of life: Results from the PALOMA-2 trial. Ann. Oncol. 2018, 29, 888-894. [CrossRef]

41. Elfgen, C.; Montagna, G.; Schmid, S.M.; Bierbauer, W.; Güth, U. Noncompliance with palliative systemic therapy in pa-tients with distant metastatic breast cancer: A blind spot for oncologists? Breast Cancer Res. Treat. 2019, 176, 469-476. [CrossRef]

42. Husinka, L.; Koerner, P.H.; Miller, R.T.; Trombatt, W. Review of cyclin-dependent kinase $4 / 6$ inhibitors in the treatment of advanced or metastatic breast cancer. J. Drug Assess. 2021, 10, 27-34. [CrossRef] [PubMed]

43. Migliaccio, I.; Bonechi, M.; McCartney, A.; Guarducci, C.; Benelli, M.; Biganzoli, L.; Di Leo, A.; Malorni, L. CDK4/6 inhibitors: A focus on biomarkers of response and post-treatment therapeutic strategies in hormone receptor-positive HER2-negative breast cancer. Cancer Treat. Rev. 2011, 93, 102136. [CrossRef] [PubMed]

44. Wander, S.A.; Zangardi, M.; Niermierko, A.; Kambadakone, A.; Kim, L.S.L.; Xi, J.; Pandey, A.K.; Spring, L.; Stein, C.; Juric, D.; et al. A multicenter analysis of abemaciclib after progression on palbociclib in patients with hormone receptor-positive (HR+)/HER2metastatic breast cancer (MBC). J. Clin. Oncol. 2019, 37, 1057. [CrossRef]

45. Costa, C.; Wang, Y.; Ly, A.; Hosono, Y.; Murchie, E.; Walmsley, C.S.; Huynh, T.; Healy, C.; Peterson, R.; Yanase, S.; et al. PTEN Loss Mediates Clinical Cross-Resistance to CDK4/6 and PI3K $\alpha$ Inhibitors in Breast Cancer. Cancer Discov. 2020, 10, 72-85. [CrossRef]

46. Fribbens, C.; O’Leary, B.; Kilburn, L.; Hrebien, S.; Garcia-Murillas, I.; Beaney, M.; Cristofanilli, M.; Andre, F.; Loi, S.; Loibl, S.; et al. Plasma ESR1 Mutations and the Treatment of Estrogen Receptor-Positive Advanced Breast Cancer. J. Clin. Oncol. 2016, 34, 2961-2968. [CrossRef]

47. Wander, S.A.; Cohen, O.; Johnson, G.N.; Kim, D.; Luo, F.; Mao, P.; Nayar, U.; Helvie, K.; Marini, L.; Freeman, S.; et al. Whole exome sequencing (WES) in hormone-receptor positive (HR+) metastatic breast cancer (MBC) to identify mediators of re-sistance to cyclin-dependent kinase 4/6 inhibitors (CDK4/6i). J. Clin. Oncol. 2018, 36, 12016. [CrossRef]

48. Brett, J.O.; Spring, L.M.; Bardia, A.; Wander, S.A. ESR1 mutation as an emerging clinical biomarker in metastatic hormone receptor-positive breast cancer. Breast Cancer Res. 2021, 23, 1-15. [CrossRef]

49. Schiavon, G.; Hrebien, S.; Garcia-Murillas, I.; Cutts, R.J.; Pearson, A.; Tarazona, N.; Fenwick, K.; Kozarewa, I.; Lopez-Knowles, E.; Ribas, R.; et al. Analysis of ESR1 mutation in circulating tumor DNA demonstrates evolution during therapy for metastatic breast cancer. Sci. Transl. Med. 2015, 7, 313. [CrossRef]

50. Raimondi, L.; Raimondi, F.M.; Pietranera, M.; Di Rocco, A.; Di Benedetto, L.; Miele, E.; Lazzeroni, R.; Cimino, G.; Spinelli, G.P. Assessment of Resistance Mechanisms and Clinical Implications in Patients with KRAS Mutated-Metastatic Breast Cancer and Resistance to CDK4/6 Inhibitors. Cancers 2021, 13, 1928. [CrossRef]

51. Schoninger, S.F.; Blain, S.W. The ongoing search for biomarkers of CDK4/6 inhibitor responsiveness in Breast Cancer. Mol. Cancer 2020, 19, 3-12. [CrossRef]

52. Vora, S.R.; Juric, D.; Kim, N.; Mino-Kenudson, M.; Huynh, T.; Costa, C.; Lockerman, E.; Pollack, S.F.; Liu, M.; Li, X.; et al. CDK 4/6 inhibitors sensitize PIK3CA mutant breast cancer to PI3K inhibitors. Cancer Cell 2014, 26, 136-149. [CrossRef] [PubMed]

53. Engelman, J.A.; Luo, J.; Cantley, L.C. The evolution of phosphatidylinositol 3-kinases as regulators of growth and metab-olism. Nat. Rev. Genet. 2020, 7, 606-619. [CrossRef]

54. Martínez-Sáez, O.; Chic, N.; Pascual, T.; Adamo, B.; Vidal, M.; Gonzalez-Farre, B.; Sanfeliu, E.; Schettini, F.; Conte, B.; Bra-soMaristany, F.; et al. Frequency and spectrum of PIK3CA somatic mutations in breast cancer. Breast Cancer Res. $2020,22,45$. [CrossRef]

55. Saal, L.H.; Holm, K.; Maurer, M.; Memeo, L.; Su, T.; Wang, X.; Yu, J.S.; Malström, P.-O.; Mansukhani, M.; Enoksson, J.; et al. PIK3CA muta-tions correlate with hormone receptors, node metastasis, and ERBB2, and are mutually exclusive with PTEN loss in human breast carcinoma. Cancer Res. 2005, 65, 2554-2559. [CrossRef] [PubMed]

56. Liu, Y.-R.; Jiang, Y.-Z.; Zuo, W.-J.; Yu, K.-D.; Shao, Z.-M. PIK3CA mutations define favorable prognostic biomarkers in operable breast cancer: A systematic review and meta-analysis. Oncotargets 2014, 7, 543-552.

57. Mosele, F.; Stefanovska, B.; Lusque, A.; Dien, A.T.; Garberis, I.; Droin, N.; Tourneau, C.L.; Sablin, M.-P.; Lacroix, L.; Enrico, D.; et al. Outcome and molecular landscape of patients with PIK3CA-mutated metastatic breast cancer. Ann. Oncol. 2020, $31,377-386$. [CrossRef] [PubMed]

58. Huang, D.; Tang, L.; Yang, F.; Jin, J.; Guan, X. PIK3CA mutations contribute to fulvestrant resistance in ER-positive breast cancer. Am. J. Transl. Res. 2019, 11, 6055-6065. [PubMed]

59. Baselga, J.; Im, S.-A.; Iwata, H.; Cortes, J.; De Laurentiis, M.; Jiang, Z.; Arteaga, C.L.; Jonat, W.; Clemons, M.; Ito, Y.; et al. Bu-parlisib plus fulvestrant versus placebo plus fulvestrant in postmenopausal, hormone receptor-positive, HER2-negative, advanced breast cancer (BELLE-2): A randomised, double-blind, placebo-controlled, phase 3 trial. Lancet Oncol. 2017, 18, 904-916. [CrossRef]

60. Dent, S.; Cortes, J.; Im, Y.-H.; Dieras, V.; Harbeck, N.; Krop, I.E.; Wilson, T.R.; Cui, N.; Schimmoller, F.; Hsu, J.Y.; et al. Phase III randomized study of taselisib or placebo with fulvestrant in estrogen receptor-positive, PIK3CA-mutant, HER2-negative, advanced breast cancer: The SANDPIPER trial. Ann. Oncol. 2021, 32, 197-207. [CrossRef] 
61. André, F.; Ciruelos, E.; Rubovsky, G.; Campone, M.; Loibl, S.; Rugo, H.S.; Iwata, H.; Conte, P.; Mayer, I.A.; Kaufman, B.; et al. Alpelisib for PIK3CA-Mutated, Hormone Receptor-Positive Advanced Breast Cancer. N Engl. J. Med. 2019, 380, $1929-1940$. [CrossRef] [PubMed]

62. Zhang, M.; Jang, H.; Nussinov, R. PI3K inhibitors: Review and new strategies. Chem. Sci. 2020, 11, 5855-5865. [CrossRef] [PubMed]

63. Blow, T.; Hyde, P.N.; Falcone, J.N.; Neinstein, A.; Vasan, N.; Chitkara, R.; Hurd, M.A.; Sardesai, S.; Lustberg, M.B.; Flory, J.H.; et al. Treating Alpelisib-Induced Hyperglycemia with Very Low Carbohydrate Diets and Sodium-Glucose Co-Transporter 2 Inhibitors: A Case Series. Integr. Cancer 2021, 20, 15347354211032284. [CrossRef] [PubMed]

64. Ciruelos, E.M.; Rugo, H.S.; Mayer, I.A.; Levy, C.; Forget, F.; Mingorance, J.I.D.; Safra, T.; Masuda, N.; Park, Y.H.; Juric, D.; et al. Patient-Reported Outcomes in Patients With PIK3CA-Mutated Hormone Receptor-Positive, Human Epidermal Growth Factor Receptor 2-Negative Advanced Breast Cancer From SOLAR-1. J. Clin. Oncol. 2021, 39, 2005-2015. [CrossRef]

65. Hester, A.; Henze, F.; Travi, C.; Harbeck, N.; Wuerstlein, R. First Experiences with Alpelisib in Clinical Routine: Case Re-ports from a German Breast Center. Breast Care. 2021, 16, 129-134. [CrossRef]

66. Jhaveri, K.; Drago, J.Z.; Shah, P.D.; Wang, R.; Pareja, F.; Ratzon, F.; Iasonos, A.; Patil, S.; Rosen, N.; Fornier, M.N.; et al. A Phase I Study of Alpelisib in Combination with Trastuzumab and LJM716 in Patients with PIK3CA-Mutated HER2-Positive Metastatic Breast Cancer. Clin. Cancer Res. 2021, 27, 3867-3875. [CrossRef]

67. Martín, M.; Chan, A.; Dirix, L.; O’Shaughnessy, J.; Hegg, R.; Manikhas, A.; Shtivelband, M.; Krivorothko, P.; Lopez, N.B.; Campone, M.; et al. A randomized adaptive phase II/III study of buparlisib, a pan-class I PI3K inhibitor, combined with paclitaxel for the treatment of HER2- advanced breast cancer (BELLE-4). Ann. Oncol. 2017, 28, 313-320. [CrossRef]

68. Priedigkeit, N.; Ding, K.; Horne, W.; Kolls, J.K.; Du, T.; Lucas, P.C.; Blohmer, J.-U.; Denkert, C.; Machleidt, A.; Inhold-Heppner, B.; et al. Acquired mutations and transcriptional remodeling in long-term estrogen-deprived locoregional breast cancer recurrences. Breast Cancer Res. 2021, 23, 1. [CrossRef]

69. Del Re, M.; Crucitta, S.; Lorenzini, G.; De Angelis, C.; Diodati, L.; Cavallero, D.; Bargagna, I.; Cinacchi, P.; Fratini, B.; Salva-dori, B.; et al. PI3K mutations detected in liquid biopsy are associated to reduced sensitivity to CDK4/6 inhibitors in meta-static breast cancer patients. Pharm. Res. 2021, 163, 105241. [CrossRef]

70. Baselga, J.; Dent, S.F.; Cortes, J.; Im, Y.-H.; Dieras, V.; Harbeck, N.; Krop, I.E.; Verma, S.; Wilson, T.R.; Jin, H.; et al. Phase III study of taselisib (GDC-0032) + fulvestrant (FULV) v FULV in patients with estrogen receptor (ER)-positive, PIK3CA-mutant (MUT), locally advanced or metastatic breast cancer (MBC): Primary analysis from SANDPIPER. J. Clin. Oncol. 2018, 36, LBA1006. [CrossRef]

71. Chang, D.-Y.; Ma, W.-L.; Lu, Y.-S. Role of Alpelisib in the Treatment of PIK3CA-Mutated Breast Cancer: Patient Selection and Clinical Perspectives. Clin. Risk Manag. 2021, 17, 193-207. [CrossRef] [PubMed]

72. Jerusalem, G.; Rorive, A.; Collignon, J. Use of mTOR inhibitors in the treatment of breast cancer: An evaluation of factors that influence patient outcomes. Breast Cancer Dove Med. Press. 2014, 6, 43-57. [CrossRef] [PubMed]

73. Gnant, M.; Baselga, J.; Rugo, H.S.; Noguchi, S.; Burris, H.A.; Piccart, M.; Hortobagyi, G.N.; Eakle, J.; Mukai, H.; Iwata, H.; et al. Effect of everolimus on bone marker levels and progressive disease in bone in BOLERO-2. J. Natl. Cancer Inst. 2013, 105, 654-663. [CrossRef] [PubMed]

74. Rogers, S.C.; Garcia, C.A.; Wu, S. Discontinuation of everolimus due to unrelated adverse events in cancer patients. J. Clin. Oncol. 2016, 34, e14020. [CrossRef]

75. Huang, H.-W.; Huang, L.-S.; Xu, Q.-N.; Wang, H.-B.; Li, X.-Y.; Lin, J.-Z. CDK4/6 inhibition versus mTOR blockade as second-line strategy in postmenopausal patients with hormone receptor-positive advanced breast cancer. Medicine (Baltimore) 2019, 98 , e13909. [CrossRef] [PubMed]

76. Piccart, M.; Hortobagyi, G.N.; Campone, M.; Pritchard, K.I.; Lebrun, F.; Ito, Y.; Noguchi, S.; Perez, A.; Rugo, H.S.; Deleu, I.; et al. Everolimus plus exemestane for hormone-receptor-positive, human epidermal growth factor receptor-2-negative ad-vanced breast cancer: Overall survival results from BOLERO-2. Ann. Oncol. 2014, 25, 2357-2362. [CrossRef] [PubMed]

77. Hortobagyi, G.N.; Chen, D.; Piccart, M.; Rugo, H.S.; Burris, H.A.; Pritchard, K.I.; Campone, M.; Noguchi, S.; Perez, A.T.; Deleu, I.; et al. Correlative Analysis of Genetic Alterations and Everolimus Benefit in Hormone Receptor-Positive, Human Epidermal Growth Factor Receptor 2-Negative Advanced Breast Cancer: Results From BOLERO-2. J. Clin. Oncol. 2016, 34, 419-426. [CrossRef] [PubMed]

78. Rozenblit, M.; Mun, S.; Soulos, P.; Adelson, K.; Pusztai, L.; Mougalian, S. Patterns of treatment with everolimus exemestane in hormone receptor-positive HER2-negative metastatic breast cancer in the era of targeted therapy. Breast Cancer Res. 2021, 23, 14. [CrossRef]

79. Jones, R.H.; Casbard, A.; Carucci, M.; Cox, C.; Butler, R.; Alchami, F.; Madden, T.-A.; Bale, C.; Bezecny, P.; Joffe, J.; et al. Ful-vestrant plus capivasertib versus placebo after relapse or progression on an aromatase inhibitor in metastatic, oestrogen receptor-positive breast cancer (FAKTION): A multicentre, randomised, controlled, phase 2 trial. Lancet Oncol. 2020, 21, 345-357. [CrossRef]

80. Rugo, H.S.; Rumble, R.B.; Macrae, E.; Barton, D.L.; Connolly, H.K.; Dickler, M.N.; Fallowfield, L.; Fowble, B.; Ingle, J.N.; Ja-hanzeb, M.; et al. Endocrine Therapy for Hormone Receptor-Positive Metastatic Breast Cancer: American Society of Clinical Oncology Guideline. J. Clin. Oncol. 2016, 34, 3069-3103. [CrossRef] 
81. Telli, M.L.; Gradishar, W.J.; Ward, J.H. NCCN Guidelines Updates: Breast Cancer. J. Natl. Compr. Canc. Netw. 2019, 17, 552-555. [PubMed]

82. Mayer, E.L.; Dueck, A.C.; Martin, M.; Rubovsky, G.; Burstein, H.J.; Bellet-Eqquerra, M.; Miller, K.D.; Zdenkowski, N.; Winer, E.P.; Pfeiler, G.; et al. Palbociclib with adjuvant endocrine therapy in early breast cancer (PALLAS): Interim analysis of a multicentre, open-label, randomised, phase 3 study. Lancet Oncol. 2021, 22, 212-222. [CrossRef]

83. Loibl, S.; Marme, F.; Martin, M.; Untch, M.; Bonnefoi, H.; Kim, S.-B.; Bear, H.; McCarthy, N.; Melé Olivé, M.; Gelmon, K.; et al. Palbociclib for Residual High-Risk Inva-sive HR-Positive and HER2-Negative Early Breast Cancer-The Penelope-B Trial. J. Clin. Oncol. 2021, 39, 1518-1530. [CrossRef]

84. Johnston, S.R.D.; Harbeck, N.; Hegg, R.; Toi, M.; Martin, M.; Shao, Z.M.; Zhang, Q.Y.; Rodriguez, J.L.M.; Campone, M.; Ham-ilton, E.; et al. Abemaciclib Combined With Endocrine Therapy for the Adjuvant Treatment of HR+, HER2-, Node-Positive, High-Risk, Early Breast Cancer (monarchE). J. Clin. Oncol. 2020, 38, 3987-3998. [CrossRef] [PubMed]

85. Saura, C.; Hlauschek, D.; Oliveira, M.; Zardavas, D.; Jallitsch-Halper, A.; de la Pena, L.; Nuciforo, P.; Ballestrero, A.; Dubsky, P.; Lombard, J.M.; et al. Neoadjuvant letrozole plus taselisib versus letrozole plus placebo in postmenopausal women with oestrogen re-ceptor-positive, HER2-negative, early-stage breast cancer (LORELEI): A multicentre, randomised, double-blind, place-bo-controlled, phase 2 trial. Lancet Oncol. 2019, 20, 1226-1238. [CrossRef] 